\title{
Future directions of palaeoecological research in the hyper-diverse Cape Floristic Region: The role of palynological studies
}

\author{
Lynne J. Quick \\ African Centre for Coastal Palaeoscience, Nelson Mandela University, Port \\ Elizabeth, South Africa
}

\begin{abstract}
The Cape Floristic Region (CFR) is a key focus area within southern Africa due to its botanical importance in terms of high levels of biodiversity as well as its rich cultural and archaeological heritage. The area is sensitive to cycles of regional and global environmental change, and palynological records obtained from the region can potentially provide valuable information regarding past vegetation dynamics and climate variability. Prior to the last decade, few high resolution palaeoenvironmental records were recovered from the CFR, and therefore its Late Quaternary environmental history was previously poorly understood. Significant progress was made over recent years and a considerable body of new palynological (as well as palaeoclimatological) evidence emerged. These new records provide greater insight into the nature and timing of past vegetation shifts and improve our understanding of how different subregions of the CFR have responded to past climate changes. They also highlight that there is a much higher degree of complexity, in terms of both vegetation and climate change, than previously thought. This paper provides a perspective on the progress made towards elucidating the palaeoecological history of the CFR, it highlights the importance of continuing and expanding upon the existing body of work and outlines current and future directions for palynological research in this hyper-diverse southwestern corner of southern Africa.
\end{abstract}

\subsection{INTRODUCTION}

The southwestern Cape of South Africa has long been recognized as a unique region particularly in terms of the distinctiveness of its flora. Due to the extraordinarily high levels of biodiversity and plant endemism found within the region it has previously been recognized as one of the six global floral kingdoms (Marloth 1908; Takhtajan et al. 1986) and is currently world-renowned as a key biodiversity hotspot (Mittermeier et al. 2004; Myers et al. 2000). The Fynbos Biome (Figure 1) and Cape Floristic Region (CFR) are considered by many to be synonymous, however the 'biome' refers only to the two dominant vegetation groups (Fynbos and Renosterveld), whereas the 'region' refers to the general geographical area and includes other vegetation types in the Afrotemperate Forest, Nama Karoo, Succulent Karoo and Albany Thicket Biomes. The CFR has been the subject of decades of intensive botanical research due to its unique floristic, evolutionary and ecological characteristics as well as its conservation appeal (e.g. Allsopp et al. 2014; Bond and Goldblatt 1984; Campbell 1985; Cowling 1992; Cowling et al. 1995; Goldblatt and Manning 2000; Rebelo et al. 2006). 

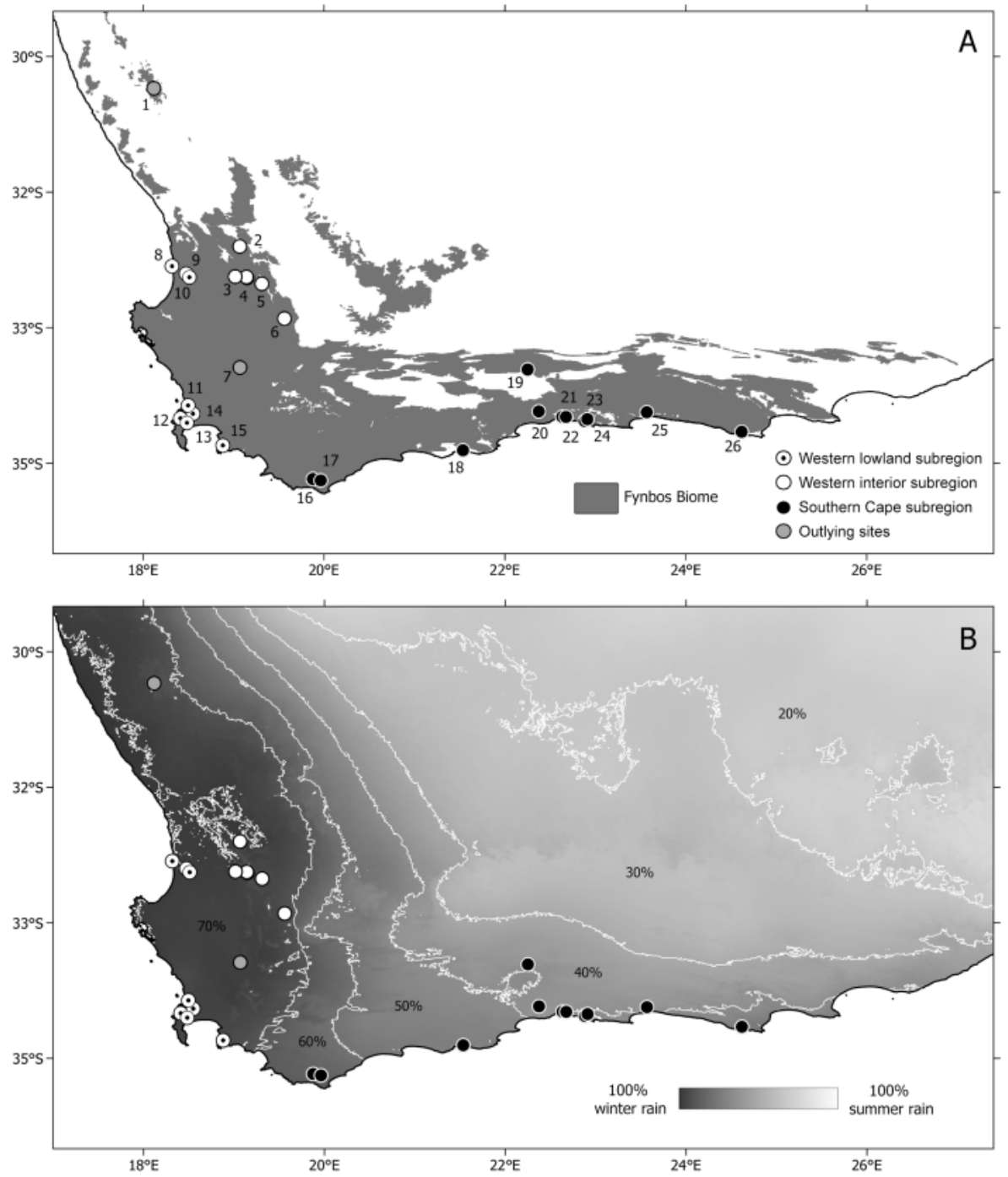

Figure 1. The distribution of fossil pollen records for the Cape Floristic Region (as demarcated by the Fynbos Biome) (A) and in relation to seasonality of rainfall (defined in terms of percentage of winter rainfall) (B). Records are grouped according to subregion and the type of archive is demarcated in brackets after the site name $(\mathrm{w}=$ wetland deposit; $\mathrm{h}=$ hyrax midden and $\mathrm{c}=$ cave deposit, hc $=$ hyena coprolites). 1 - Groenkloof (w) (MacPherson et al. 2018), 2 - Pakhuis Pass (h) (Scott and Woodborne 2007b, a), 3 - De Rif (h) (Quick et al. 2011; Valsecchi et al. 2013), 4 - Driehoek and Sneeuberg vleis (w) (Meadows and Sugden 1991), 5 - Truitjes Kraal 4 (h) (Chase et al. 2015b; Meadows et al. 2010), 6 - Katbakkies 1 (h) (Chase et al. 2015b; Meadows et al. 2010), 7 - Vankraal Spring (w) (Forbes et al. 2018), 8 - Elands Bay Cave (c) (Meadows and Baxter 1999), 9 - Grootdrift (w) (Meadows et al. 1996), 10 - Klaarfontein Springs (w) (Meadows and Baxter 2001), 11 - Rietvlei (w) (Schalke 1973), 12 - Cecilia Cave (c) (Meadows and Baxter 1999), 13 - Princessvlei (w) (Cordova et al. 2019; Neumann et al. 2011), 14 - Cape Flats (w) (Schalke 1973),

15 - Cape Hangklip (w) (Schalke 1973), 16 - Voelvlei (w) (Carr et al. 2006), 17 - Soetendalsvlei (w) (Carr et al. 2006), 18 - Rietvlei Still Bay (w) (Quick et al. 2015), 19 - Boomplaas (c) (Deacon et al. 1984), 20 - Norga (w) (Scholtz 1986), 21 - Eilandvlei (w) (Quick et al. 2018), 22 - Bo Langvlei (w) (du Plessis et al. 2020), 23 - Groenvlei (w)

(Martin 1968), 24 - Vankervelsvlei (w) (Irving and Meadows 1997; Quick et al. 2016), 25 - Platbos 1 (w) (MacPherson et al. 2019), 26 - Oyster Bay (hc) (Carrion et al. 2000) [Data: South African National Biodiversity Institute (2006- ). The Vegetation Map of South Africa, Lesotho and Swaziland, Mucina, L., Rutherford, M.C. and Powrie, L.W. (Editors), Online, http://bgis.sanbi.org/SpatialDataset/Detail/18, Version 2018]. 
The southwestern Cape is also important from a climatic perspective as it is a particularly dynamic region in terms of long-term climate change. Unlike most of South Africa which receives summer rainfall, the CFR mainly falls within the winter rainfall zone (WRZ) (sensu Chase and Meadows 2006), presently receiving most of its rainfall during the austral winter when the southern westerly storm track migrates northward (Taljaard 1996; Tyson 1986; Tyson and Preston-Whyte 2000). Whereas during the austral summer, the westerlies and the South Atlantic Anticyclone shift southward limiting the influence of both frontal systems and tropical moisture sources (Reason et al. 2006; Tyson and Preston-Whyte 2000), resulting in warm, dry summer conditions. This Mediterranean-type climatic setting has played an important part in the development of the CFR and is thought to have helped foster the region's botanical diversity (Bradshaw and Cowling 2014; Cowling and Lombard 2002; Cowling et al. 2015; Goldblatt 1978; Linder 2005; Linder et al. 1992). While long-term climatic stability during the Pliocene and Pleistocene is hypothesized to be one of the key factors for the diversification of the Cape flora (Verboom et al. 2014; Cowling and Lombard 2002; Cowling et al. 2015; Cowling et al. 1997; Linder 2005), little direct evidence is available. Furthermore, species diversity within the CFR is not homogeneous and at finer spatial and temporal scales the concept of climatic stability driving diversity and species richness becomes more complex (Cowling 1992; Cowling and Lombard 2002; Cowling et al. 1997).

Palaeoecological studies within the CFR have the potential to contribute important insight into biodiversity patterns and processes, providing long-term perspectives of climatic and ecosystem changes. The CFR has a rich archaeological history as it is the locality for speciation events that culminated in the evolution of anatomically and behaviourally modern humans (Brown et al. 2009; Brown et al. 2012; Henshilwood et al. 2001; Henshilwood et al. 2002; Marean 2010; Marean et al. 2007). Determining the environmental context for these events represents an essential tool to understand human evolution, behaviour, and dispersal patterns. Not only can palaeoecology provide important insights into long-term human evolutionary trends but palaeoecological studies within the CFR can also help contextualize more recent archaeological trends such as migration patterns of indigenous pastoralists (e.g. Deacon 1992; Sadr 1998, 2008)) and their possible impact on late Holocene environments and ecosystems (e.g. Meadows and Baxter 2001; Neumann et al. 2011).

In terms of palaeoecological data, palynology represents the principal method available to determine the responses of vegetation to environmental change over various spatial and temporal scales (Bennett and Willis 2001; Birks et al. 2016; Faegri and Iversen 1989). Despite being a key focus area within southern Africa (as outlined above) no systematic study of the palynology of the Cape Flora has been conducted, considerable efforts have however been made towards the generation of individual fossil pollen records.

This paper presents a brief synopsis of the current state of the palaeoecological record of the CFR, with a focus on the pollen records that have been produced over the last decade. The role that palynology can play in advancing palaeoecological research is further explored by outlining current initiatives and future directions for palynological research within the CFR.

\subsection{THE LATE QUATERNARY PALAEOECOLOGICAL HISTORY OF THE CAPE FLORISTIC REGION}

As this is a short perspective piece, this section is not an exhaustive review of all the palynological records that fall within the CFR (although all pollen records are presented in Figure 1), but rather focuses on several of the most recently established records.

In general, the significant advances that were made in palaeoenvironmental/palaeoecological research could not have been achieved without the generation and evaluation of multiple lines of proxy evidence as well as the use of unique environmental archives. This is particularly the 
case for the CFR as organic sediments (which are traditionally the main source of fossil pollen) are relatively rare, given the semi-arid nature of the region. Records from rock hyrax (Procavia capensis) middens represent the single most significant contribution to a more nuanced and detailed understanding of the palaeoclimates of the CFR as they are remarkably sensitive to environmental changes and contain a great diversity of proxies (e.g. fossil pollen, stable isotopes, plant biomarkers) (Chase et al. 2012; Scott 1990). Hyrax middens are however largely preserved only within the more arid inland mountainous regions of the CFR (i.e. within mountain ranges associated with the Cape Fold Belt) while more conventional palaeoecological archives, such as coastal lakes and wetlands, are found along the west and southern Cape coasts. Records derived from these sites helped to provide a more balanced coverage across the CFR (Figure 1). While inherent differences exist between pollen assemblages derived from hyrax middens and those from wetland deposits (i.e. pollen spectra from wetland deposits often include high proportions of local hydrophilic taxa whereas pollen found in hyrax middens is likely a more direct representation of the terrestrial vegetation), each record is carefully considered in the context of its unique environmental, ecological, hydrological and geomorphological setting - all of which can influence pollen production, dispersal and representation. These factors are also taken into account when comparing records across the CFR.

That the existing spatial heterogeneity within the CFR is a key determining factor for the nature of any identified palaeoenvironmental changes is not a new observation (Chase and Meadows 2007; Cowling 1992; Cowling and Holmes 1992; Meadows and Baxter 1999), however, with more records generated, and the increasing availability of high-resolution data, we are now able to explore this theory to a fuller extent. To best illustrate how distinct subregions of the CFR have responded differently to palaeoenvironmental changes and to highlight the contribution of the most recent published pollen records, two key subregions - the southern Cape coast and the Cederberg mountains - are briefly considered.

\subsubsection{Palaeoecology of the southern Cape: The significance of coastal environments}

The southern Cape coastal plain forms the eastern lowland subregion of the CFR (Figure 1) and is influenced by atmospheric dynamics associated with both the winter and summer rainfall zones (the aseasonal or year-round rainfall zone; sensu Chase and Meadows 2007).

While several sediment cores have been extracted from the Vankervelsvlei wetland site (Irving 1998; Irving and Meadows 1997), limited reliable palaeoenvironmental evidence has emanated from these studies due to poor chronological control and inconsistent pollen preservation. However, with the addition of optically stimulated luminescence (OSL) as a dating technique, Quick et al. (2016) established a chronology for a sediment sequence spanning the last 140,000 years. The variability within the pollen assemblage from this record indicates a complex response to the transition from interglacial to glacial conditions. In general, the dominance of afrotemperate forest pollen from Marine Isotope Stage (MIS) 5d (c. 108-96 ka) alludes to enhanced summer rainfall under warmer conditions allowing for the development of more extensive forests in the area (Quick et al. 2016). In contrast, the pollen from the last glacial period was dominated by fynbos types indicating cooler temperatures and a more seasonal winter-dominated rainfall regime (Quick et al. 2016).

Due to the virtual absence of palaeoenvironmental data from the southern Cape covering MIS 5 to MIS 3, the Vankervelsvlei pollen data represents an important contribution, however as no pollen was preserved from $c .27-8.7 \mathrm{ka}$, the record is incomplete. This highlights a particularly frustrating trend of the Last Glacial Maximum (LGM; 26.5-19 cal ky BP (Clark et al. 2009)) period being absent from pollen sequences from the southern Cape coast. Either the pollen records recovered from the subregion do not extend as far back as the LGM (e.g. du Plessis et al. 2020; Martin 1968; Scholtz 1986) or as is the case of Vankervelsvlei and Rietvlei-Still Bay (Quick et al. 2015), there is limited to no pollen preserved. Supplementary proxy data from Vankervelsvlei 
and Rietvlei-Still Bay suggest that conditions were likely quite arid during the LGM (Quick et al. 2015; Quick et al. 2016), which could explain the lack of pollen preservation, and is supported by evidence of decreased moisture availability from other studies from the subregion (Chase and Meadows 2007, and references therein). Other factors that could potentially have contributed to decreased wetland productivity and a lack of pollen preservation within these coastal or near-coastal wetlands during the LGM are lower sea-levels (affecting groundwater recharge and regional hydrology) and enhanced aeolian activity. As pollen is found within the LGM sections of records from the western interior (e.g. the Pakhuis Pass and De Rif hyrax midden records (Quick et al. 2011; Scott and Woodborne 2007a, b; Valsecchi et al. 2013)) and the southwestern Cape coast within the modern WRZ (Pearly Beach record (Quick et al., 2021), the lack of preservation seems to be confined to the year-round rainfall portion of the southern Cape (Southern Cape subregion, Figure 1) and therefore likely to be tied to subregion-scale changes in moisture availability. This theory can be tested with the acquisition of new sites from both the coast and the interior.

With an average sample resolution of 57 years, the pollen record from the coastal lake of Eilandvlei (Quick et al. 2018; Figure 1) represents the most continuous and highest resolution record of Holocene vegetation change for the southern Cape subregion. Similar to the Vankervelsvlei record, the Eilandvlei pollen assemblage primarily reflects shifts in the abundance of afrotemperate forest and fynbos taxa. For example, fynbos dominates the assemblage during the early Holocene, indicating generally cool, seasonal conditions, whereas increasing percentages of afrotemperate forest taxa from $3.5 \mathrm{cal}$ ky BP to present day suggest that the late Holocene was characterized by a long-term trend of steadily increasing moisture availability (Quick et al. 2018). Comparisons of this high-resolution record with regional and extra-regional palaeoclimatic data highlight the complex nature of southern Cape climate dynamics (Quick et al. 2018). The similarities between the Eilandvlei record and records from more tropical regions of South Africa led to the proposal that summer rainfall is of great importance in terms of maintaining high moisture availability and that the Agulhas Current could be responsible for transmitting this signal of tropical variability along the coast (Chase and Quick 2018; Quick et al. 2018). These insights emphasize the importance of considering proxy evidence, including fossil pollen, from sites on the coast separately from those from the interior and caution against extrapolating results beyond the subregion scale.

\subsubsection{Cederberg palaeoenvironments: Environmental stability vs. extreme palaeoclimatic changes}

The Cederberg mountains represent the core of the western interior CFR subregion (Figure 1) and while free from the direct, localized influence of coastal dynamics, the palaeoenvironmental history of the Cederberg is no less complex than that of the southern Cape coast.

Several fossil pollen records from this subregion infer that extremely muted changes in vegetation composition took place during the last glacial and Holocene (Meadows et al. 2010; Meadows and Sugden 1991; Meadows and Sugden 1993; Quick et al. 2011). It has been suggested that mountain fynbos (the dominant vegetation type in the area) is highly resilient to changes in moisture availability, which could account for the low-amplitude variability within these palaeoecological records (Quick et al. 2011). However, this is contrasted by a growing body of data that indicates more dynamic patterns in vegetation and, especially, climate change (Chase et al. 2019; Chase et al. 2015a; Chase et al. 2011; Scott and Woodborne 2007a, b; Valsecchi et al. 2013). This evidence mainly consists of stable isotope records derived from hyrax middens situated within the central (Chase et al. 2011; Chase et al. 2015), northern (Chase et al. 2019) and eastern (Chase et al. 2015) sections of the Cederberg. These records indicate that substantial, rapid changes in hydroclimatic conditions occurred since the LGM, and that while the drivers 
of climate dynamics appear to be shared across the subregion, there are distinct local responses, resulting in a great degree of variability across short spatial gradients (Chase et al. 2019).

The discrepancies between the older pollen records and the more recent stable isotope records could be related to differences in the nature of the information obtained from these two proxies. Stable carbon and nitrogen isotope data from hyrax middens are excellent recorders of changes in moisture availability (Chase et al. 2012) whereas palynological data is more nuanced and it can be difficult to disentangle ecological and climatic drivers of vegetation change. A further possibility is that while species turnover may be high, because it is generally only possible to identify pollen to genus or family level, this variability is not captured within the pollen assemblages.

It is clear from the emerging complexity of the palaeoenvironmental dynamics within these two subregions that substantial variability can occur across relatively short distances and interpolations beyond site level cannot always be reliably applied to regional syntheses.

\subsection{CURRENT AND FUTURE DIRECTIONS FOR PALAEOECOLOGICAL RESEARCH IN THE CAPE FLORISTIC REGION}

We now have a more nuanced understanding of palaeoenvironmental change within the CFR, however new high-resolution data are still required to fully explore subregional variability and to provide a more comprehensive understanding of the climate dynamics, drivers and the impact of climate change on CFR environments. There is great potential for fossil pollen data to contribute to this research agenda and to provide long-term perspectives of ecological dynamics within the CFR. The following sections outline current and potential future research directions that align to these goals.

\subsubsection{The influence of the Agulhas Current on coastal palaeoenvironments}

To expand on the theory outlined in Chase and Quick (2018) that a strong dipole in hydroclimatic conditions exist between the coast and interior during the Holocene, and that the Agulhas Current acts as a vector for the propagation of tropical southeast African climate signals to the southern Cape, more data is required. For a clearer understanding of the spatiotemporal dynamics of this hypothesized relationship additional high-resolution records extending into the last glacial period are needed from both the interior and coastal subregions of the southern Cape as well as from offshore (i.e. sea-surface temperature records). To begin to address this gap, a new project (by the author and collaborators) is currently underway (2020-2023) that focuses on the generation of palaeoenvironmental data, particularly fossil pollen, from wetland sites situated on a west-east transect along the southern Cape coastline.

\subsubsection{Exploring steep palaeoenvironmental gradients in the Cederberg mountains}

As previously outlined, the findings from the high-resolution stable isotope data from the Cederberg suggest that considerable palaeoclimatic change occurred across the subregion during the last glacial and Holocene (Chase et al. 2019). To fully evaluate and contextualize these findings, more sites from transects across the subregion are required. A range of proxies (such as stable isotopes, pollen, plant biomarkers, phytoliths and microcharcoal) will be analysed. New pollen data would be especially useful as it is still unclear as to whether vegetation change was in fact relatively muted or if the pollen records currently in existence are not of high enough spatial or temporal resolution to adequately capture the variability evident in the stable isotope records. 


\subsubsection{Palaeoenvironments of the eastern Cape: The final frontier?}

Encompassing the transition from fynbos to Albany/subtropical thicket as well as from fynbos to Succulent Karoo, the eastern Cape represents an important, understudied eastern boundary of the CFR. Palaeoecological data for the eastern Cape is extremely limited and no palynological research has been conducted within the Albany Thicket biome. Only one pollen record exists for the region and this record, derived from hyena coprolite samples from a Middle Stone Age archaeological site, has no chronology and the pollen content was not sufficient for a detailed palaeoenvironmental reconstruction to be performed (Carrion et al. 2000; Figure 1). There are two additional publications that include pollen data from sites situated within the Eastern Cape Province, however both of these sites fall outside the CFR: the Dunedin and Salisbury vlei pollen records from the Winterberg escarpment (Meadows and Meadows 1988) and the more recently published preliminary pollen results from ongoing archaeological research at Waterfall Bluff, eastern Pondoland (Esteban et al. 2020; Fisher et al. 2020).

There is great scope for the generation of new pollen records from both the montane (e.g. the Baviaanskloof mountains) and the coastal regions (e.g. between Tsitsikamma and Port Elizabeth). Stable isotope data from a hyrax midden site within the Baviaanskloof provide new evidence for a high degree of spatiotemporal climatic variability during the Holocene (Chase et al. 2020). The generation of pollen data from this midden is currently underway, this data will be able to shed light on how vegetation within this ecotonal subregion of the CFR may have responded to the documented changes in hydroclimatic variability.

\subsubsection{Bridging the gap between palaeoecology and ecology}

Despite the similarities in their names, ecology and palaeoecology have historically been almost entirely distinct fields of research. Both fields have contributed to this disassociation: While ecologists generally recognize the need for long-term perspectives of vegetation change, they have been sceptical of the robustness of palaeoecological research methods and the inferences that are drawn from proxy records. Consequently, they have had reservations about the usefulness and reliability of palaeoecological data for addressing ecological questions. While this may once have been a legitimate concern, there have been vast methodological improvements to the generation of palaeoecological data which have resulted in much higher resolution, more accurately dated, proxy sequences (Birks et al. 2016). Conversely, due to the different spatial and temporal scales, palaeoecologists have often assumed that contemporary ecology is too far removed methodologically and theoretically from their field to be truly applicable. They have tended to focus on directly answering climate-related questions and in doing so have often overlooked the ecological associations of the data which has significant implications for palaeoclimatic reconstructions.

While several studies integrating ecological theory and palynological research have been conducted elsewhere in South Africa (e.g. Gillson and Duffin 2007; Gillson and Ekblom 2020; Gillson and Marchant 2014) until recently, this approach had not been attempted for the CFR. Drawing from the relatively muted changes within two late Holocene pollen records derived from sediment cores from biome boundaries (MacPherson et al. 2018; MacPherson et al. 2019), Gillson et al. (2020) present new hypotheses exploring possible ecological mechanisms to explain the apparent resilience of fynbos to environmental change. An assessment of how the ecosystem resilience and resistance hypotheses outlined in Gillson et al. (2020) align to the greater shifts in fynbos-forest dynamics documented in other palaeoecological records from ecotonal regions of the CFR (e.g. du Plessis et al. 2020; Quick et al. 2018; 2016) remains to be undertaken. However these studies as well as Forbes et al. (2018) highlight the potential for applying a more analytical ecological lens to CFR palynological records.

Fire is a major driving force in most Mediterranean-type ecosystems including fynbos (Cowling 1992). Without fire, fynbos communities become senescent and other plant types can 
invade into the biome (Cowling et al. 1992; Mucina and Rutherford 2006). Information on past fire regimes is therefore particularly important in order to understand changes at the plant community level as well as shifts in biome boundaries, especially boundaries shared with fireintolerant communities such as forest and thicket (Mucina and Rutherford 2006). Microcharcoal abundances (which are routinely counted simultaneously with pollen) can be used to reconstruct local and regional fire regimes (Cowling et al. 1997). Determining fire intensities from charcoal found in sedimentary sequences is now possible as a result of the development of a new method (Gosling et al. 2019), this method should be explored within the context of the CFR.

By providing a better understanding of ecological responses to natural and anthropogenic impacts, palaeoecological data can directly contribute to conservation management and restoration practices, however this will rely on the establishment of effective multidisciplinary working groups (Gillson, this volume; Manzano et al. 2020).

\subsubsection{New methods and resources}

The CREST (Climate REconstruction SofTware) method developed by Chevalier et al. (2014) has been very successful in producing quantitative climate reconstructions for southern Africa using contemporary climate data, modern plant distributions and fossil pollen records (Chase et al. 2015a; Chase et al. 2015b; Chevalier and Chase 2015; Chase et al. 2017; Chevalier et al. 2021; Cordova et al. 2017; Lim et al. 2016). A major advantage of this method is that a large modern pollen database (which does not currently exist for the CFR) is not required. The steep environmental gradients and coastal settings of many of the CFR pollen records have proven to introduce a great degree of complexity to the application of CREST within this region. However, there certainly still is scope for its application particularly with the addition of a new resource:

A 'by-product' of the CREST method has given rise to the 'Atlas of southern African pollen taxa: Distributions and Climatic Affinities' (Chevalier et al. this volume) which will greatly improve, refine and standardize qualitative interpretations of fossil pollen data as well as quantitative reconstructions (such as CREST). This reference atlas includes a series of diagnostic tools and results based on statistical analyses of modern distributions of common southern African pollen taxa in relation to key climate variables. This new resource reduces the subjectivity often inherent in more qualitative interpretations and presents more accurate determination of absolute and relative climate sensitivities of southern African pollen types, including a large proportion of CFR taxa.

The recent digitization of CFR pollen reference material (originally from the Palaeoecological Laboratory in the Department of Environmental and Geographical Science, University of Cape Town) and the establishment of a new open access, searchable electronic database (http://pollen.mandela.ac.za) represents a new primary palynological resource. While the resurrection of the African Pollen Database (APD, Vincens et al. 2007) and its integration into the Neotoma Palaeoecology Database (Goring et al. 2015), will ensure that previously published and new pollen datasets are archived within an open access online platform (Ivory et al. 2020). If the majority of fossil pollen records for the CFR were included in the new APD - Neotoma database, new forms of spatiotemporal analyses could be conducted which would provide greater insight into ecosystem-climate linkages across the region.

\subsection{CONCLUSIONS}

While our understanding of paleoenvironmental change within the CFR has been greatly improved by the establishment of recent high-resolution palaeoclimatic and palaeoecological records, fundamental questions still remain relating to the full extent of the subregional variability of both climate and vegetation change, and how these subregions are associated/disassociated with each 
other. Further insight into the long-term environmental dynamics within the CRF will be possible if the spatial and temporal coverage of sites are expanded and by employing the new methods and resources now available.

In the face of global climate change and ever-increasing ecological uncertainty as a result of unprecedented climatic and societal changes, there has never been a more urgent need for scientific collaboration and the establishment of multidisciplinary studies. The wide sphere of applicability of pollen analysis to a multitude of fields (e.g. vegetation modelling, restoration ecology, conservation biology, aerobiology and archaeology) highlights the incredible potential, both current and future, of palaeoecology's role within multidisciplinary studies. Hopefully in the coming years palaeoecological research within the CFR will continue to advance and contribute to a greater understanding of the region's unique biodiversity and climatic history.

\section{ACKNOWLEDGEMENTS}

While this paper is a personal perspective, the conceptual frameworks, ideas and insights are the culmination of collaboration particularly with Michael Meadows and Brian Chase, who originally set me on this research path. Two anonymous reviewers are thanked for their insightful comments and suggestions on an earlier version of this paper.

\section{REFERENCES}

Allsopp, N., Colville, J.F. and Verboom, G.A., 2014, Fynbos: ecology, evolution, and conservation of a megadiverse region. Oxford University Press, USA.

Bennett, K.D. and Willis, K.J., 2001, Pollen. In Tracking Environmental Change Using Lake Sediments. Volume 3: Terrestrial, Algal, and Siliceous Indicators, edited by Smol, J.P., Birks, H.J.B., Last, W.M., (Dordrecht: Kluwer Academic Publishers), pp. 5-26.

Birks, H.J.B. and Birks, H.H. and Ammann, B., 2016, The fourth dimension of vegetation. Science 354, pp. 412-413, 10.1126/science.aai8737.

Bond, P. and Goldblatt, P., 1984, Plants of the Cape flora: A descriptive catalogue, In Journal of South African Botany, Supplementary Volume, edited by Eloff, J.N., pp. 1-455.

Bradshaw, P.L. and Cowling, R.M., 2014. Landscapes, rock types, and climate of the Greater Cape Floristic Region. In Fynbos: Ecology, Evolution, and Conservation of a Megadiverse Region, edited by Allsopp, N., Colville, J.F., Verboom, G.A. (Oxford: Oxford University Press) pp. 26-46.

Brown, K.S., Marean, C.W., Herries, A.I.R., Jacobs, Z., Tribolo, C., Braun, D., Roberts, D.L., Meyer, M.C. and Bernatchez, J., 2009, Fire as an engineering tool of early modern humans. Science, 325, pp. 859-862, 10.1126/science.1175028.

Brown, K.S., Marean, C.W., Jacobs, Z., Schoville, B.J., Oestmo, S., Fisher, E.C., Bernatchez, J., Karkanas, P. and Matthews, T., 2012, An early and enduring advanced technology originating 71,000 years ago in South Africa. Nature 491, pp. 590-593, 10.1038/nature11660.

Campbell, B.M., 1985, A Classification of the Mountain Vegetation of the Fynbos Biome. (Pretoria: Botanical Research Institute, Deptartment of Agriculture and Water Supply).

Carr, A.S., Thomas, D.S.G., Bateman, M.D., Meadows, M.E. and Chase, B., 2006, Late Quaternary palaeoenvironments of the winter-rainfall zone of southern Africa: Palynological and sedimentological evidence from the Agulhas Plain. Palaeogeography, Palaeoclimatology, Palaeoecology, 239, pp. 147-165, 10.1016/j.palaeo.2006.01.014.

Carrion, J.S., Brink, J.S., Scott, L. and Binneman, J.N.F., 2000, Palynology and palaeoenvironment of Pleistocene hyaena coprolites from an open-air site at Oyster Bay, Eastern Cape coast, South Africa. South African Journal of Science, 96, pp. 449-453. 
Chase, B., Boom, A., Carr, A., Chevalier, M., Quick, L., Verboom, A. and Reimer, P., 2019, Extreme hydroclimate gradients within the western Cape Floristic region of South Africa since the Last Glacial Maximum. Quaternary Science Reviews, 219, pp. 297-307, 10.1016/j.quascirev.2019.07.006.

Chase, B.M. and Meadows, M.E., 2007, Late Quaternary dynamics of southern Africa's winter rainfall zone. Earth-Science Reviews, 84, pp. 103-138, 10.1016/j.earscirev.2007.06.002.

Chase, B.M., Quick, L.J., Meadows, M.E., Scott, L., Thomas, D.S.G. and Reimer, P.J., 2011, Late-glacial interhemispheric climate dynamics revealed in South African hyrax middens. Geology, 39, pp. 19-22, 10.1130/G31129.1.

Chase, B.M., Scott, L., Meadows, M.E., Gil-Romera, G., Boom, A., Carr, A.S., Reimer, P.J., Truc, L., Valsecchi, V. and Quick, L.J., 2012, Rock hyrax middens: A palaeoenvironmental archive for southern African drylands. Quaternary Science Reviews, 56, pp. 107-125, 10.1016/j.quascirev.2012.08.018.

Chase, B.M., Boom, A., Carr, A.S., Carré, M., Chevalier, M., Meadows, M.E., Pedro, J.B., Stager, J.C. and Reimer, P.J., 2015a, Evolving southwest African response to abrupt deglacial North Atlantic climate change events. Quaternary Science Reviews, 121, pp. 132-136, 10.1016/j.quascirev.2015.05.023.

Chase, B.M., Lim, S., Chevalier, M., Boom, A., Carr, A.S., Meadows, M.E. and Reimer, P.J., $2015 \mathrm{~b}$, Influence of tropical easterlies in southern Africa's winter rainfall zone during the Holocene. Quaternary Science Reviews, 107, pp. 138-148, 10.1016/j.quascirev.2014.10.011.

Chase, B.M., Chevalier, M., Boom, A. and Carr, A.S., 2017, The dynamic relationship between temperate and tropical circulation systems across South Africa since the last glacial maximum. Quaternary Science Reviews, 174, pp. 54-62, 10.1016/j.quascirev.2017.08.011.

Chase, B.M. and Quick, L.J., 2018, Influence of Agulhas forcing of Holocene climate change in South Africa's southern Cape. Quaternary Research, 90, pp. 303-309, 10.1017/qua.2018.57.

Chase, B.M., Boom, A., Carr, A.S., Quick, L.J. and Reimer, P.J., 2020, High-resolution record of Holocene climate change dynamics from southern Africa's temperate-tropical boundary, Baviaanskloof, South Africa. Palaeogeography, Palaeoclimatology, Palaeoecology, 539, article: 109518, 10.1016/j.palaeo.2019.109518.

Chevalier, M., Cheddadi, R. and Chase, B.M., 2014, CREST (Climate REconstruction SofTware): a probability density function (PDF)-based quantitative climate reconstruction method. Climate of the Past, 10, pp. 2081-2098, 10.5194/cp-10-2081-2014.

Chevalier, M. and Chase, B.M., 2015. Southeast African records reveal a coherent shift from high- to low-latitude forcing mechanisms along the east African margin across last glacial-interglacial transition. Quaternary Science Reviews 125, pp. 117-130, 10.1016/j.quascirev.2015.07.009.

Chevalier, M., Chase, B.M., Quick, L.J., Dupont, L.M., and Johnson, T.C., 2021, Temperature change in subtropical southeastern Africa during the past 790,000 yr. Geology, 49(1), pp. 71-75, 10.1130/G47841.1.

Chevalier, M., Chase, B.M., Quick, L.J. and Scott, L., this volume, An atlas of southern African pollen types and their climatic affinities. Palaeoecology of Africa, 35, chapter 15, 10.1201/9781003162766-15.

Clark, P.U., Dyke, A.S., Shakun, J.D., Carlson, A.E., Clark, J., Wohlfarth, B., Mitrovica, J.X., Hostetler, S.W. and McCabe, A.M., 2009, The last glacial maximum. Science, 325, pp. 710-714, 10.1126/science.1172873.

Cordova, C.E., Scott, L., Chase, B.M. and Chevalier, M., 2017, Late Pleistocene-Holocene vegetation and climate change in the Middle Kalahari, Lake Ngami, Botswana. Quaternary Science Reviews, 171, pp. 199-215, 10.1016/j.quascirev.2017.06.036.

Cordova, C.E., Kirsten, K.L., Scott, L., Meadows, M. and Lücke, A., 2019, Multi-proxy evidence of late-Holocene paleoenvironmental change at Princessvlei, South Africa: The 
effects of fire, herbivores, and humans. Quaternary Science Reviews, 221, article: 105896, 10.1016/j.quascirev.2019.105896.

Cowling, R.M., 1992, The Ecology of Fynbos: Nutrients, Fire, and Diversity. (Cape Town: Oxford University Press).

Cowling, R.M. and Holmes, P.M., 1992, Endemism and speciation in a lowland flora from the Cape Floristic Region. Biological Journal of the Linnean Society, 47, pp. 367-383, 10.1111/j.1095-8312.1992.tb00675.x.

Cowling, R.M., Richardson, D.M., Paterson-Jones, C., 1995, Fynbos: South Africa's Unique Floral Kingdom. (Vlaeberg: Fernwood Press).

Cowling, R.M., Richardson, D.M., Schulze, R.E., Hoffman, M.T., Midgley, J.J. and HiltonTaylor, C., 1997. Species diversity at the regional scale. In Vegetation of Southern Africa, edited by Cowling, R.M., Richardson, D.M., Pierce, S.M, (Cambridge: Cambridge University Press), pp. 447-273.

Cowling, R.M. and Lombard, A.T., 2002, Heterogeneity, speciation/extinction history and climate: explaining regional plant diversity patterns in the Cape Floristic Region. Diversity and Distributions 8, pp. 163-179, 10.1046/j.1472-4642.2002.00143.x.

Cowling, R.M., Potts, A.J., Bradshaw, P.L., Colville, J., Arianoutsou, M., Ferrier, S., Forest, F., Fyllas, N.M., Hopper, S.D. and Ojeda, F., 2015, Variation in plant diversity in mediterraneanclimate ecosystems: The role of climatic and topographical stability. Journal of Biogeography, 42, pp. 552-564, 10.1111/jbi.12429.

Deacon, H.J., Deacon, J., Scholtz, A., Thackeray, J.F. and Brink, J.S., 1984, Correlation of palaeoenvironmental data from the Late Pleistocene and Holocene deposits at Boomplaas Cave, southern Cape. In Late Cainozoic Palaeoclimates of the Southern Hemisphere, edited by Vogel, J.C., (Rotterdam: Balkema), pp. 339-360.

Deacon, H.J., 1992, Human settlement. In The Ecology of Fynbos: Nutrients, Fire and Diversity, edited by Cowling, R.M. (Cape Town: Oxford University Press), pp. 260-270.

du Plessis, N., Chase, B.M., Quick, L.J., Haberzettl, T., Kasper, T. and Meadows, M.E., 2020, Vegetation and climate change during the Medieval Climate Anomaly and the Little Ice Age on the southern Cape coast of South Africa: Pollen evidence from Bo Langvlei. The Holocene, 30(12), pp. 1716-1727, 10.1177/0959683620950444.

Esteban, I., Bamford, M.K., House, A., Miller, C.S., Neumann, F.H., Schefuß, E., Pargeter, J., Cawthra, H.C. and Fisher, E.C., 2020. Coastal palaeoenvironments and hunter-gatherer plantuse at Waterfall Bluff rock shelter in Mpondoland (South Africa) from MIS 3 to the Early Holocene. Quaternary Science Reviews, 250, article: 106664, 10.1016/j.quascirev.2020. 106664.

Faegri, K. and Iversen, J., 1989, Textbook of Pollen Analysis, 4th Edition, (Chichester: John Wiley \& Sons).

Fisher, E.C., Cawthra, H.C., Esteban, I., Jerardino, A., Neumann, F.H., Oertle, A., Pargeter, J., Saktura, R.B., Szabó, K. and Winkler, S., 2020, Coastal occupation and foraging during the last glacial maximum and early Holocene at Waterfall Bluff, eastern Pondoland, South Africa. Quaternary Research, 97, pp. 1-41, 10.1017/qua.2020.26.

Forbes, C.J., Gillson, L. and Hoffman, M.T., 2018, Shifting baselines in a changing world: Identifying management targets in endangered heathlands of the Cape Floristic Region, South Africa. Anthropocene 22, pp. 81-93, 10.1016/j.ancene.2018.05.001.

Gillson, L. and Duffin, K., 2007, Thresholds of potential concern as benchmarks in the management of African savannahs. Philosophical Transactions of the Royal Society B: Biological Sciences, 362, pp. 309-319, 10.1098/rstb.2006.1988.

Gillson, L. and Marchant, R., 2014, From myopia to clarity: sharpening the focus of ecosystem management through the lens of palaeoecology. Trends in Ecology \& Evolution, 29, pp. 317-325, 10.1016/j.tree.2014.03.010. 
Gillson, L. and Ekblom, A., 2020, Using palaeoecology to explore the resilience of southern African savannas. Koedoe, 62, pp. 1-12, 10.4102/koedoe.v62i1.1576.

Gillson, L., MacPherson, A.J. and Hoffman, M.T., 2020, Contrasting mechanisms of resilience at mesic and semi-arid boundaries of fynbos, a mega-diverse heathland of South Africa. Ecological Complexity, 42, article: 100827, 10.1016/j.ecocom.2020.100827.

Gillson, L., this volume, The role of palaeoecology in conserving African ecosystems. Palaeoeoclogy of Africa, 35, chapter: 24, 10.1201/9781003162766-24.

Goldblatt, P., 1978, An analysis of the flora of southern Africa: its characteristics, relationships, and origins. Annals of the Missouri Botanical Garden 65, pp. 369-436, 10.2307/2398858.

Goldblatt, P. and Manning, J., 2000, Cape Plants. A Conspectus of the Cape Flora of South Africa. (Pretoria and St. Louis: National Botanical Institute and Missouri Botanical Gardens).

Goring, S., Dawson, A., Simpson, G., Ram, K., Graham, R., Grimm, E. and Williams, J., 2015, Neotoma: A programmatic interface to the Neotoma Paleoecological Database. Open Quaternary 1(1), article 2, 10.5334/oq.ab.

Gosling, W.D., Cornelissen, H. and McMichael, C.N.H., 2019, Reconstructing past fire temperatures from ancient charcoal material. Palaeogeography, Palaeoclimatology, Palaeoecology, 520, pp. 128-137, 10.1016/j.palaeo.2019.01.029.

Henshilwood, C.S., d'Errico, F., Marean, C.W., Milo, R.G. and Yates, R., 2001, An early bone tool industry from the Middle Stone Age at Blombos Cave, South Africa: implications for the origins of modern human behaviour, symbolism and language. Journal of Human Evolution, 41, pp. 631-678, 10.1006/jhev.2001.0515.

Henshilwood, C.S., d'Errico, F., Yates, R., Jacobs, Z., Tribolo, C., Duller, G.A.T., Mercier, N., Sealy, J.C., Valladas, H., Watts, I. and Wintle, A.G., 2002, Emergence of modern human behavior: Middle stone age engravings from South Africa. Science, 295, pp. 1278-1280, $10.1126 /$ science. 1067575 .

Irving, S.J.E. and Meadows, M.E., 1997, Radiocarbon chronology and organic matter accumulation at Vankervelsvlei, near Knysna, South Africa. South African Geographical Journal, 79, pp. 101-105, 10.1080/03736245.1997.9713630.

Irving, S.J.E., 1998. Late Quaternary palaeoenvironments at Vankervelsvlei, near Knysna, South Africa, Department of Environmental and Geographical Sciences. University of Cape Town, Cape Town.

Ivory, S., Lézine, A.-M., Grimm, E. and Williams, J.W., 2020, Relaunching the African Pollen Database: Abrupt change in climate and ecosystems, Past Global Changes Magazine, 28(1), pp. 26.

Lim, S., Chase, B.M., Chevalier, M. and Reimer, P.J., 2016, 50,000 years of vegetation and climate change in the southern Namib Desert, Pella, South Africa. Palaeogeography, Palaeoclimatology, Palaeoecology, 451, pp. 197-209, 10.1016/j.palaeo.2016.03.001.

Linder, H.P., 2005. Evolution of diversity: The Cape flora. Trends in Plant Science, 10, pp. 536-541, 10.1016/j.tplants.2005.09.006.

Linder, H.P., Meadows, M. and Cowling, R.M., 1992, History of the Cape Flora. In The Ecology of Fynbos: nutrients, fire and diversity, edited by Cowling, R.M. (Cape Town: Oxford University Press), pp. 113-134.

MacPherson, A., Gillson, L. and Hoffman, M., 2018, Climatic buffering and anthropogenic degradation of a Mediterranean-type shrubland refugium at its semi-arid boundary, South Africa. The Holocene, 28, pp. 651-666, 10.1177/0959683617735582.

MacPherson, A.J., Gillson, L. and Hoffman, M.T., 2019, Between-and within-biome resistance and resilience at the fynbos-forest ecotone, South Africa. The Holocene, 29, 1801-1816, $10.1177 / 0959683619862046$.

Manzano, S., Julier, A.C.M., Dirk, C.J., Razafimanantsoa, A.H.I., Samuels, I., Petersen, H., Gell, P., Hoffman, M.T. and Gillson, L., 2020, Using the past to manage the future: the role 
of palaeoecological and long-term data in ecological restoration. Restoration Ecology, 28, pp. 1335-1342, 10.1111/rec.13285.

Marean, C.W., Bar-Matthews, M., Bernatchez, J., Fisher, E., Goldberg, P., Herries, A.I.R., Jacobs, Z., Jerardino, A., Karkanas, P., Minichillo, T., Nilssen, P.J., Thompson, E., Watts, I., and Williams, H.M., 2007, Early human use of marine resources and pigment in South Africa during the Middle Pleistocene. Nature, 449, pp. 905-908, 10.1038/nature06204.

Marean, C.W., 2010, Pinnacle Point Cave 13B (Western Cape Province, South Africa) in context: The Cape Floral kingdom, shellfish, and modern human origins. Journal of Human Evolution, 59, pp. 425-443, 10.1016/j.jhevol.2010.07.011.

Marloth, R., 1908. Das Kapland: Insonderheit das Reich der Kapflora, das Waldgebiet und die Karroo, pflanzengeographisch dargestellt. (Jena: G. Fischer).

Martin, A.R.H., 1968. Pollen analysis of Groenvlei lake sediments, Knysna (South Africa). Review of Palaeobotany and Palynology 7, pp. 107-144, 10.1016/0034-6667(68)90029-8.

Meadows, M.E. and Baxter, A.J., 1999, Late Quaternary palaeoenvironments of the southwestern Cape, South Africa: A regional synthesis. Quaternary International, 57-8, pp. 193-206.

Meadows, M.E. and Baxter, A.J., 2001, Holocene vegetation history and palaeoenvironments at Klaarfontein Springs, Western Cape, South Africa. The Holocene 11, pp. 699-706, 10.1191/09596830195726.

Meadows, M.E., and Meadows, K.F., 1988, Late Quaternary vegetation history of the Winterberg Mountains, Eastern Cape, South Africa. South African Journal of Science, 84, pp. 253-259.

Meadows, M.E. and Sugden, J.M., 1991, A vegetation history of the last 14,000 years on the Cederberg, southwestern Cape Province. South African Journal of Science, 87, 34-43.

Meadows, M.E. and Sugden, J.M., 1993, The late Quaternary palaeoecology of a floristic kingdom: the southwestern Cape, South Africa. Palaeogeography, Palaeoclimatology, Palaeoecology, 101, pp. 271-281, 10.1016/0031-0182(93)90019-F.

Meadows, M.E., Baxter, A.J. and Parkington, J., 1996, Late Holocene environments at Verlorenvlei, Western Cape Province, South Africa. Quaternary International, 33, pp. 81-95, 10.1016/1040-6182(95)00092-5.

Meadows, M.E., Seliane, M. and Chase, B.M., 2010, Holocene palaeoenvironments of the Cederberg and Swartruggens mountains, Western Cape, South Africa: pollen and stable isotope evidence from hyrax dung middens. Journal of Arid Environments, 74, pp. 786-793.

Mittermeier, R.A., Robles Gil, P., Hoffman, M., Pilgrim, J., Brooks, T., Goettsch Mittermeier, C., Lamoreux, J. and da Fonseca, G.A.B., 2004, Hotspots Revisited. (Mexico City: CEMEX, Agrupación Sierra Madre, S.C.).

Myers, N., Mittermeier, R.A., Mittermeier, C.G., da Fonseca, G.A.B. and Kent, J., 2000, Biodiversity hotspots for conservation priorities. Nature, 403, pp. 853-858, 10.1038/35002501.

Neumann, F.H., Scott, L., Bamford, M.K., 2011, Climate change and human disturbance of fynbos vegetation during the late Holocene at Princess Vlei, Western Cape, South Africa. The Holocene, 21, pp. 1137-1149, 10.1177/0959683611400461.

Quick, L.J., Chase, B.M., Meadows, M.E., Scott, L. and Reimer, P.J., 2011, A 19.5 kyr vegetation history from the central Cederberg Mountains, South Africa: Palynological evidence from rock hyrax middens. Palaeogeography, Palaeoclimatology, Palaeoecology 309, pp. 253-270, 10.1016/j.palaeo.2011.06.008.

Quick, L.J., Carr, A.S., Meadows, M.E., Boom, A., Bateman, M.D., Roberts, D.L., Reimer, P.J. and Chase, B.M., 2015, A Late Pleistocene-Holocene multi-proxy record of palaeoenvironmental change from Still Bay, southern Cape Coast, South Africa. Journal of Quaternary Science, 30, pp. 870-885, 10.1002/jqs.2825.

Quick, L.J., Meadows, M.E., Bateman, M.D., Kirsten, K.L., Mäusbacher, R., Haberzettl, T. and Chase, B.M., 2016, Vegetation and climate dynamics during the last glacial period in the fynbos-afrotemperate forest ecotone, southern Cape, South Africa. Quaternary International, 404, pp. 136-149, 10.1016/j.quaint.2015.08.027. 
Quick, L.J., Chase, B.M., Wündsch, M., Kirsten, K.L., Chevalier, M., Mäusbacher, R., Meadows, M.E. and Haberzettl, T., 2018, A high-resolution record of Holocene climate and vegetation dynamics from the southern Cape coast of South Africa: pollen and microcharcoal evidence from Eilandvlei. Journal of Quaternary Science, 33, pp. 487-500, 10.1002/jqs.3028.

Quick, L.J., Chase, B.M., Carr, A.S., Chevalier, M., Grober, B.A. and Meadows, M.E., 2021, A 25,000-year record of climate and vegetation change from the southwestern Cape coast, South Africa. Quaternary Research, 10.1017/qua.2021.31.

Reason, C.J.C., Landman, W. and Tennant, W., 2006, Seasonal to decadal prediction of southern African climate and its links with variability of the Atlantic ocean. Bulletin of the American Meteorological Society, 87, pp. 941-955, 10.1175/BAMS-87-7-941.

Rebelo, A.G., Boucher, C., Helme, N., Mucina, L. and Rutherford, M.C., 2006, Fynbos Biome. In The vegetation of South Africa, Lesotho and Swaziland, edited by Mucina, L., Rutherford, M.C. (Preroria: South African National Biodiversity Institute), pp. 221-299.

Sadr, K., 1998, The first herders at the Cape of Good Hope. African Archaeological Review 15, pp. 101-132, 10.1023/A:1022158701778.

Sadr, K., 2008, Invisible herders? The archaeology of Khoekhoe pastoralists. Southern African Humanities, 20, pp. 179-203.

Schalke, H.J.W.G., 1973, The Upper Quaternary of the Cape Flats area. Scripta Geologica, 15, pp. 1-57.

Scholtz, A., 1986, Palynological and Palaeobotanical Studies in the Southern Cape. University of Stellenbosch, Stellenbosch, South Africa.

Scott, L., 1990. Hyrax (Procaviidae) and dassie rat (Petromuridae) middens in palaeoenvironmental studies in Africa. In Packrat Middens: The Last 40,000 Years of Biotic Change,edited by Betancourt, J.L., van Devender, T.R., Martin, P.S. (Tucson: University of Arizona Press), pp. 408-427.

Scott, L. and Woodborne, S., 2007a, Vegetation history inferred from pollen in Late Quaternary faecal deposits (hyraceum) in the Cape winter-rain region and its bearing on past climates in South Africa. Quaternary Science Reviews, 26, pp. 941-953, 10.1016/j.quascirev.2006.12.012.

Scott, L. and Woodborne, S., 2007b, Pollen analysis and dating of late Quaternary faecal deposits (hyraceum) in the Cederberg, Western Cape, South Africa. Review of Palaeobotany and Palynology, 144, pp. 123-134, 10.1016/j.revpalbo.2006.07.004.

Takhtajan, A., Crovello, T.J. and Cronquist, A., 1986, Floristic Regions of the World. (Berkeley: University of California Press).

Taljaard, J., 1996, Atmospheric Circulation Systems, Synoptic Climatology and Weather Phenomena of South Africa. South African Weather Service Technical Paper 32. (Pretoria: South African Weather Service).

Tyson, P.D., 1986, Climatic Change and Variability in Southern Africa. (Cape Town: Oxford University Press).

Tyson, P.D. and Preston-Whyte, R.A., 2000, The Weather and Climate of Southern Africa. Oxford University Press, Cape Town.

Valsecchi, V., Chase, B.M., Slingsby, J.A., Carr, A.S., Quick, L.J., Meadows, M.E., Cheddadi, R. and Reimer, P.J., 2013, A high resolution 15,600-year pollen and microcharcoal record from the Cederberg Mountains, South Africa. Palaeogeography, Palaeoclimatology, Palaeoecology, 387, pp. 6-16, 10.1016/j.palaeo.2013.07.009.

Vincens, A., Lézine, A.-M., Buchet, G., Lewden, D. and Le Thomas, A., 2007, African pollen database inventory of tree and shrub pollen types. Review of Palaeobotany and Palynology, 145, pp. 135-141, 10.1016/j.revpalbo.2006.09.004.

Verboom, G.A., Linder, H.P., Forest, F., Hoffmann, V., Bergh, N.G. and Cowling, R.M., 2014, Cenozoic assembly of the Greater Cape flora. In Fynbos: Ecology, Evolution, and Conservation of a Megadiverse Region, edited by Allsopp, N., Colville, J.F., and Verboom, G.A., (Oxford: Oxford University Press), pp. 93-118. 